\title{
Urban form and vacant shops: can one explain the other? A case study in Portugal
}

\author{
Miguel Saraiva' ${ }^{2}$, Teresa Sá Marques', Paulo Pinho² \\ ${ }^{1}$ CEGOT Research Centre; Faculty of Arts of the University of Porto; Porto, Portugal \\ ${ }^{2}$ CITTA - Research Centre for Territory, Transports and Environment; Faculty of Engineering, \\ University of Porto; Porto, Portugal \\ E-mail:miguelmsaraiva@gmail.com, teresasamarques@gmail.com,pcpinho@fe.uppt
}

\begin{abstract}
Shopping is much more than a wealth-generator in post-modern societies; it is intrinsically linked with the way people experience the city and an indivisible part of their day-to-day social experiences. Consequently, the literature has gradually recognized that commercial geographies are not just a consequence of economic market logics. It has been proven that there is a relationship between store-types and urban morphology, and that commerce is an important catalyst for urban regeneration and revitalization. Thus, the urban form can also be a cause for the lack of success of a shop. The amount of vacant shops has been signaled as an important problem in urban areas, affecting the structure and the identity of neighbourhoods, and reflects the negative effects of the economic-crisis. Strategies to overcome this problem are usually economically-oriented and fail to capitalize on the new-found relationships between store-success and urban morphology. Thus this research wishes to test whether there are indeed correlations between specific morphological features and the existence of vacant shops, and consequently to discuss how changes in the urban environment can contribute to overcome, and even prevent, such cases. The geographical distribution of vacant shops in a sample of Portuguese cities was set against morphological variables such as building age or centrality in the network. Positive association was found, for example, between new developments and vacant shops, questioning the need for more store space in certain areas; and, particularly outside central neighborhoods, between open shops and high travel-through (rather than highly central) segments.
\end{abstract}

Keywords: commerce; medium-sized cities; urban morphology; space syntax; urban planning

\section{Introduction - The relationship of commercial activity with urban morphology}

Today, the evolution in store types, purchase options and the shopping experience as a whole (Hart and Dale, 2014, Pecoraro and Uusitalo, 2014) has changed the laws of store-attractiveness and hence re-shaped the geography of urban retail systems (Saraiva and Pinho, 2017).

Consequently, although the market necessities still explain in great part the geoeconomic trends of the commercial sector, the features of urban spaces have of late been recognized as also having a strong correlation with the location, characteristics and ultimately the success of shops (Saraiva and Pinho, 2017). Indeed, commerce is now recognized as a driver of urban development and regeneration (Findlay and Sparks, 2009, Barata-Salgueiro and Erkip, 2014).

Several authors (see review in Saraiva, 2013) have uncovered how the concentration of certain store types in specific areas can influence, or be influenced by, the spatial and morphological (re)configuration of cities. 
Yoshida and Omae (2005) and Jostens and van Nes (2005), for example, have noted distinct morphological characteristics, highly intercorrelated, of blocks, buildings and buildingto-land ratios in commercial locations. Saraiva (2013), however, has questioned this allocation of non-changeable morphological features to all commercial buildings. Analyzing the entire urban perimeter of Portuguese cities, the author notes that most commercial variables have even distributions between the various types of buildings and blocks. Only when separating between particular retail types are morphological distinctions made clear. For example, around $90 \%$ of all fashion shops are located either in central main streets or inside peripheral shopping centres. Consequently, store patterns are correlated to the configuration of urban hierarchies and their intrinsic connectivity though micro and macro networks.

This last point has been particularly explored, with several authors comparing commercial patterns with transport/ accessibility configurations at various scales. In these studies, morphological elements are generally characterized through connectivity, either distance to closest intersections or the weight of the store's street segment in the network, according to concepts like those of 'integration' and 'betweeness/choice' of Space Syntax.

For Jingman (2009) and van Nes (2005) the city's commercial centres are unequivocally in syntax centres, both at a local and a global scale. But the same author has found a weak cooccurrence between integration and shops in Berlin (Joosten and Van Nes, 2005) and Porta et al (2009) suggest that the strongest correlation is with global betweenness, not integration. Indeed, for Hillier and Iida (2005) there will be a gradation according to the necessities of each store type, something which is confirmed by Sarma (2006), Villain (2011) or Saraiva (2013). Anchor, multi-purpose or multi-comparison stores may need to be at central locations but functions whose movement is just attracted coincidentally are more dispersed and may opt for strategic locations with high throughmovement potential or serving local catchment areas. On the other hand, convenience and first necessity stores are transversal, correlating with to- and through-movement, and centrality and segregation, as they drift towards residential neighbourhoods.

Furthermore, in suburbia or smaller cities other patterns can occuras a natural consequence of their form and structure. Highly integrated streets but with intense vehicular traffic may be unattractive for stores, which may select other locations, closer to market. And outside central locations, stores could even function better in high 'choice' axes (leading to the city centre) or, if they require space but have strong self-attraction potential, in network segregated locations (Saraiva, 2013).

\section{The problem of vacant shops and the research hypothesis}

Works such as that of Brázio (2013) in Portugal or Michou (2013) in Greece have displayed how much the proliferation of vacant shops can have a high impact on the configuration and identity of urban areas. Retail decline and vacant shops have unequivocally been related to urban, market, and consumer tastes' change, and used as proxys for analyzing gentrification (Baker and Wood, 2010) and the consequences of recession (Katyoka and Wyatt, 2008, Wrigley and Dolega, 2011).

Three main causes are identified for vacant shops. First, the competition of large scale establishments, catering to the postmodern convenience-oriented society (Baker, 2002, Reimers and Clulow, 2004). Second, the decline of the viability and vitality of downtowns in terms of sociality and well-being (Hickman, 2013, Burns and Willis, 2011), environment/ economic deterioration(Whysall, 2011, Ferreri, 2015), unemployment (Gospodini, 2012), and the lateness of the return of consumers' and investors' confidence (Whysall, 2011). And third, there is the possibility that a given area may in fact not have the structural necessity for more shops, something with is hardly considered outside private locations (Saraiva, 2013).

Only a few authors actually regard vacant shops as healthy, as when they are deemed as a necessary step in the regeneration of city 
areas (Cachinho, 2014). Short term vacancies associated to continuous changing of tenants may indicate and above average economic activity and increased competition (Katyoka and Wyatt, 2008). The promotion of temporary, creative and sustainable spatial re-use of these spaces (Ferreri, 2015, Ziehl and Oßwald, 2015) may stimulate development and attract capital.

However, although there are many document cases of successful retail-led regeneration processes (Findlay and Sparks, 2009, BarataSalgueiro and Erkip, 2014), the emphasis of planners and designers on the particular case of vacant shops is mostly placed after-the-fact. Vacancy rate is sometimes part of the range of indicators that describe the urban and economic rise and decline of a given area (Colin, 2010, Balsas, 2014), but is rarely regarded as an instrument for change. If, as the literature has shown, a particular retail environment can strongly contribute to increase the resilience and vitality of a certain urban area; then an unsuitable urban environment can also contribute to the lack of success of a shop. With that in mind, this study tests if there are correlations between specific morphological features and the appearance of vacant retail sites, and consequently contributes to the understanding of how morphological changes

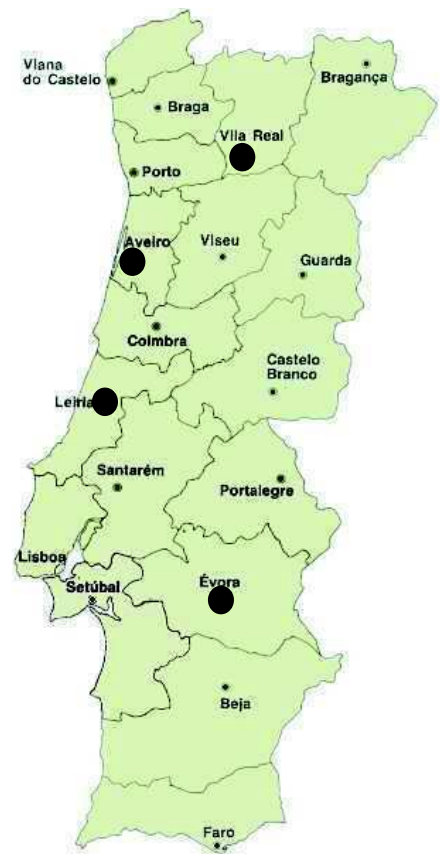

Figure 1.

Location of the case study cities in Portugal can contribute to overcome, and prevent, such cases.

\section{Methodology}

This study stems from a wider research project that analysed the relationships between commercial spaces and urban form and structure in four Portuguese medium-sized cities (Saraiva and Pinho, 2017). The four cities; Vila Real, Aveiro, Leira, Évora (Figure 1) were selected due to their different locations in the country, sizes, number of inhabitants (between 20-60 thousand) and roles in the respective regional urban hierarchies.

The case study area comprised of the official urban perimeter limit set by each respective municipal plan. This area was further divided, for analysis sake, in two parts; the 'city center' - corresponding mostly to the downtown area and the historical city nucleus; and the remainder 'periphery'. An extensive data collecting process was performed at store/ building level (see Saraiva, 2013).

Commercial spaces were catalogued by activity type, morpho-functional insertion in the building and street, and status (open or vacant). Vacant shops were divided into closed or empty. Closed shops still maintain billboards outside and/or products inside, but have closed due to licensing, financial or even personal problems. Empty shops are completely vacant, with many having never been occupied at all since construction.

Streets were characterized according to their type, width and accessibility (measured through Space Syntax). Blocks were characterized according to typology (full to hollow) and land-use mix. Buildings were characterized according to their type, amount of use, height, area, and age.

A total of 7.898 individual shop spaces, in the four cities, were thus georeferenced. Of these 1.312 (around 17\%) were catalogued as vacant. First, statistics related to vacant shops were crossed with geographical and morphological patterns of each city. Second, a closer attention was given to the location of vacant shops in relation to a Space Syntax analysis of street segments. 


\begin{tabular}{|c|c|c|c|c|c|}
\hline Cities & & Vila Real & Aveiro & Leiria & Évora \\
\hline \multirow{2}{*}{$\begin{array}{l}\text { Intervention } \\
\text { area }\left(\mathrm{m}^{2}\right)\end{array}$} & City & 23.662 .406 & 17.856 .603 & 36.259 .245 & 13.474 .660 \\
\hline & $\%$ City Center & $13,1 \%$ & $13,3 \%$ & $10,6 \%$ & $7,9 \%$ \\
\hline \multirow{2}{*}{$\begin{array}{l}\text { Number of } \\
\text { shops }\end{array}$} & City & 1.397 & 2.221 & 2.505 & 1.735 \\
\hline & $\%$ City Center & $68,2 \%$ & $56,5 \%$ & $56,0 \%$ & $48,4 \%$ \\
\hline \multirow{4}{*}{$\begin{array}{c}\% \text { of Vacant } \\
\text { shops }\end{array}$} & Total & $9 \%$ & $18 \%$ & $20 \%$ & $15 \%$ \\
\hline & Empty & $3 \%$ & $15 \%$ & $14 \%$ & $9 \%$ \\
\hline & Closed & $6 \%$ & $3 \%$ & $6 \%$ & $6 \%$ \\
\hline & $\%$ City Center & $81,4 \%$ & $57,4 \%$ & $54,6 \%$ & $40,4 \%$ \\
\hline \multirow{3}{*}{$\begin{array}{l}\% \text { of vacant } \\
\text { shops in } \\
\text { post } 1975 \\
\text { buildings }\end{array}$} & City & $60,6 \%$ & $\mathbf{5 0}, 6 \%$ & $72,2 \%$ & $50,9 \%$ \\
\hline & City Center & $62 \%$ & $31,2 \%$ & $66,8 \%$ & $2 \%$ \\
\hline & Periphery & $54,2 \%$ & $76,9 \%$ & $78,9 \%$ & $\$ 4,9 \%$ \\
\hline \multirow{3}{*}{$\begin{array}{l}\text { Number of } \\
\text { floors of } \\
\text { buildings } \\
\text { with vacant } \\
\text { shops }\end{array}$} & City & $\begin{array}{l}5(24 \%), 2(20 \%) \\
\text { and } 4 \text { floors }(17 \%)\end{array}$ & $\begin{array}{l}3(26 \%), 2(17 \%) \\
\text { and } 4 \text { floors }(17 \%)\end{array}$ & $\begin{array}{r}4(24 \%), 5(22 \%) \\
\text { and } 3 \text { floors }(20 \%)\end{array}$ & $\begin{array}{l}2(36 \%), 3(28 \%) \\
\text { and } 1 \text { floor }(22 \%)\end{array}$ \\
\hline & City Center & $\begin{array}{l}5(25 \%), 2(17 \%) \\
\text { and } 4 \text { floors }(16 \%)\end{array}$ & $\begin{array}{l}3(32 \%), 2(19 \%) \\
\text { and } 6 \text { floors }(19 \%)\end{array}$ & $\begin{array}{l}4(23 \%), 3(20 \%), 5 \\
\text { and } 6 \text { floors }(15 \%)\end{array}$ & $\begin{array}{l}2(53 \%) \text { and } 3 \\
\text { floors }(35 \%)\end{array}$ \\
\hline & Periphery & $\begin{array}{l}2(33 \%), 4(21 \%), \\
\text { and } 5 \text { floors }(21 \%)\end{array}$ & $\begin{array}{l}4(18 \%), 3(17 \%), \\
\text { and } 5 \text { floors }(17 \%)\end{array}$ & $\begin{array}{l}5(28 \%), 4(24 \%) \\
\text { and } 3 \text { floors }(19 \%)\end{array}$ & $\begin{array}{l}1(31 \%), 2(25 \%) \\
\text { and } 3 \text { floors }(23 \%)\end{array}$ \\
\hline \multirow{3}{*}{$\begin{array}{l}\text { Building and } \\
\text { street } \\
\text { integration } \\
\text { of Vacant } \\
\text { Shops }\end{array}$} & City & $\begin{array}{l}\text { Next to other store } \\
\text { spaces in the ground } \\
\text { floor (gf) of a } \\
\text { residential building } \\
\qquad(60 \%)\end{array}$ & $\begin{array}{l}\text { Next to other stores in } \\
\text { the gf of a residential } \\
\text { building }(41 \%) \text { or a } \\
\text { building with homes } \\
\text { and services }(25 \%)\end{array}$ & $\begin{array}{l}\text { Next to other stores in } \\
\text { the gf of a residential } \\
\text { building ( } 48 \% \text { ) or a } \\
\text { building with homes } \\
\text { and services }(27 \%)\end{array}$ & $\begin{array}{l}\text { Next to other stores } \\
\text { in the gf of a } \\
\text { residential building } \\
\qquad(43 \%)\end{array}$ \\
\hline & City Center & $\begin{array}{l}\text { Next to other stores in } \\
\text { the gf of a residential } \\
\text { building }(63 \%)\end{array}$ & $\begin{array}{l}\text { Next to other stores in } \\
\text { the gf of a residential } \\
\text { building }(55 \%) \text { or a } \\
\text { building with homes } \\
\text { and services }(20 \%)\end{array}$ & $\begin{array}{l}\text { Next to other stores in } \\
\text { the gf of a residential } \\
\text { building ( } 43 \% \text { ) or a } \\
\text { building with homes } \\
\text { and services ( } 32 \%)\end{array}$ & $\begin{array}{l}\text { Next to other stores } \\
(52 \%) \text { or isolated } \\
(20 \%) \text { in the gf of a } \\
\text { residential building }\end{array}$ \\
\hline & Periphery & $\begin{array}{l}\text { In a puiposely built } \\
\text { structure }(25 \%) \text {, or in } \\
\text { the gf of a residential } \\
\text { building without } \\
\text { adjacent stores (21\%) }\end{array}$ & $\begin{array}{l}\text { Next to other stores in } \\
\text { the gf of a residential } \\
\text { building }(41 \%) \text { or a } \\
\text { building with homes } \\
\text { and services }(35 \%)\end{array}$ & $\begin{array}{l}\text { Next to other stores in } \\
\text { the gf of a residential } \\
\text { building }(55 \%) \text { or a } \\
\text { building with homes } \\
\text { and services }(21 \%)\end{array}$ & $\begin{array}{l}\text { Next to other stores in } \\
\text { the gf of a residential } \\
\text { building ( } 37 \% \text { ) or a } \\
\text { building with homes } \\
\text { and services ( } 20 \% \text { ) }\end{array}$ \\
\hline \multirow{3}{*}{$\begin{array}{l}\text { Most } \\
\text { common } \\
\text { activity type } \\
\text { identifiable } \\
\text { in 'closed" } \\
\text { shops }\end{array}$} & City & $\begin{array}{c}\text { Restaurants/ Cafes } \\
(18 \%) \text { and Services } \\
(11 \%)\end{array}$ & $\begin{array}{l}\text { Restaurants/ Cafes } \\
(7 \%) \text { and Home } \\
\text { products }(5 \%)\end{array}$ & $\begin{array}{l}\text { Services }(10 \%) \text { and } \\
\text { Restaurants/ Cafes } \\
\qquad(8 \%)\end{array}$ & $\begin{array}{c}\text { Restaurants / Cafes } \\
(15 \%) \text {, Services and } \\
\text { Home (both } 6 \% \text { ) }\end{array}$ \\
\hline & City center & $\begin{array}{l}\text { Restaurants Cafes } \\
(16 \%) \text { and Services } \\
(12 \%)\end{array}$ & $\begin{array}{c}\text { Restaurants Cafés }(7 \%) \\
\text { and Services }(4 \%)\end{array}$ & $\begin{array}{c}\text { Services }(10 \%) \text { and } \\
\text { Restaurants Cafés ( } 9 \%)\end{array}$ & $\begin{array}{l}\text { Restaurants Cafés } \\
(15 \%) \text { and Home } \\
(12 \%)\end{array}$ \\
\hline & Periphery & $\begin{array}{l}\text { Restaurants Cafés } \\
(29 \%) \text { and Food \& } \\
\text { Beverage }(21 \%)\end{array}$ & $\begin{array}{c}\text { Restaurants Cafés ( } 6 \% \text { ) } \\
\text { and Services }(5 \%)\end{array}$ & $\begin{array}{c}\text { Services }(10 \%) \text { and } \\
\text { Restaurants Cafes ( } 8 \%)\end{array}$ & $\begin{array}{l}\text { Restaurants/Cafes } \\
(12 \%) \text { and Services } \\
(6 \%)\end{array}$ \\
\hline
\end{tabular}

Table 1.

Characterizing data of case studies and vacant shops 


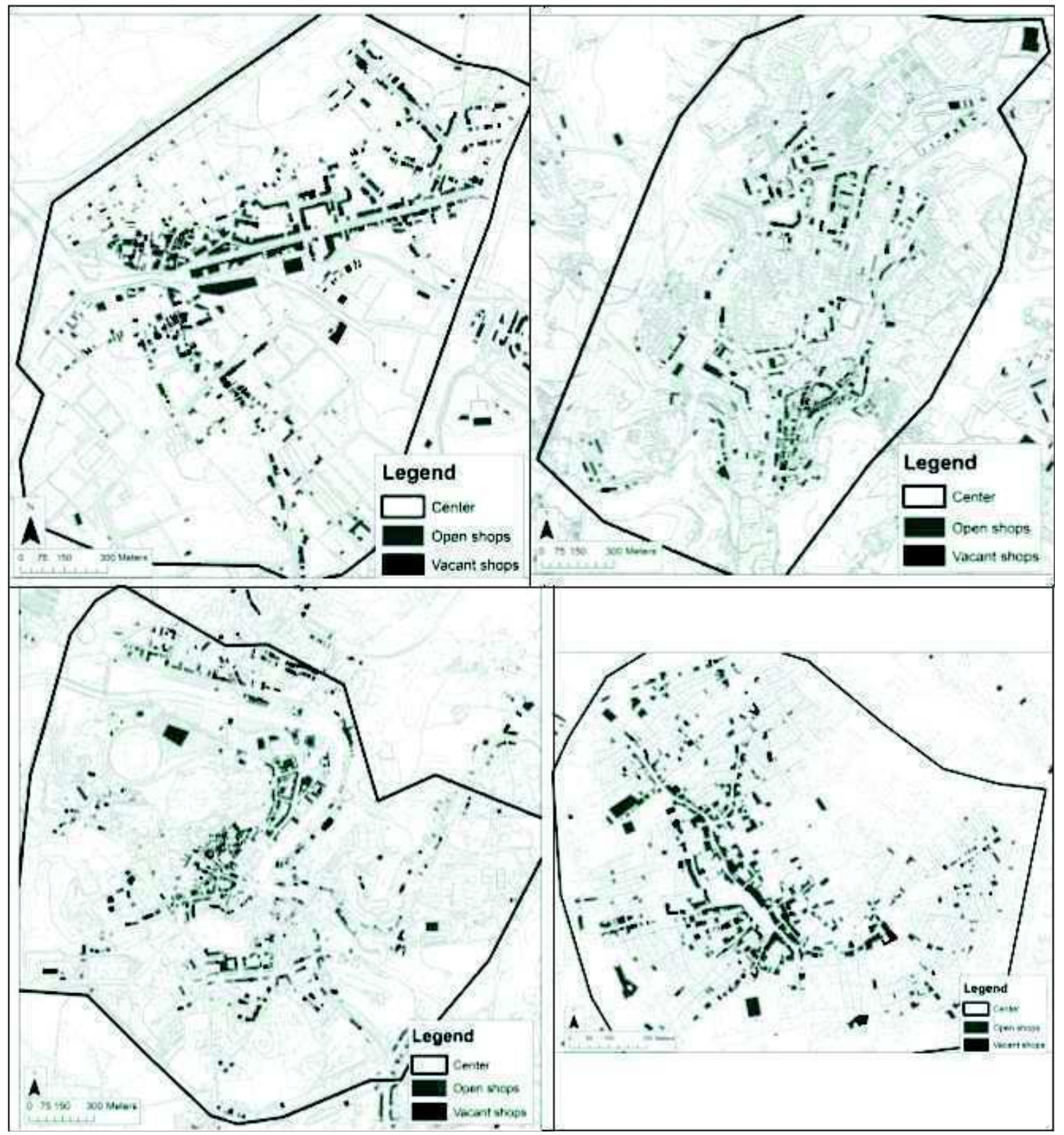

Figure 2.

Vacant shops in the city centres of Aveiro, Vila Real, Leiria and Évora

\section{The pattern of vacant shops}

Table 1 shows that around $10-20 \%$ of all shop spaces in the four cities are vacant. These are mostly located in commercial rows adjacent to other stores on the ground floors of 3-4 floor buildings with upper residential or service occupation, and predominantly constructed after 1975 (50-70\%).

In city centers, vacant shops are mainly either in the traditional areas, such as old historical blocks, composed by a more condensed street network and smaller building heights; or in larger axes of higher multifunctional buildings of recent construction (Figure 2).

In the first location vacant shops are mostly associated to smaller, second-level commercial streets, adjoining major traditional commercial hubs, which have now been replaced by close-by newer, wider, more accessible and integrated shopping streets/multi-commercial establishments. It is also here that most closed shops were found, a clear side of downturn in historical centres.

On the contrary, the second location is mostly constituted by empty shops. It can be 


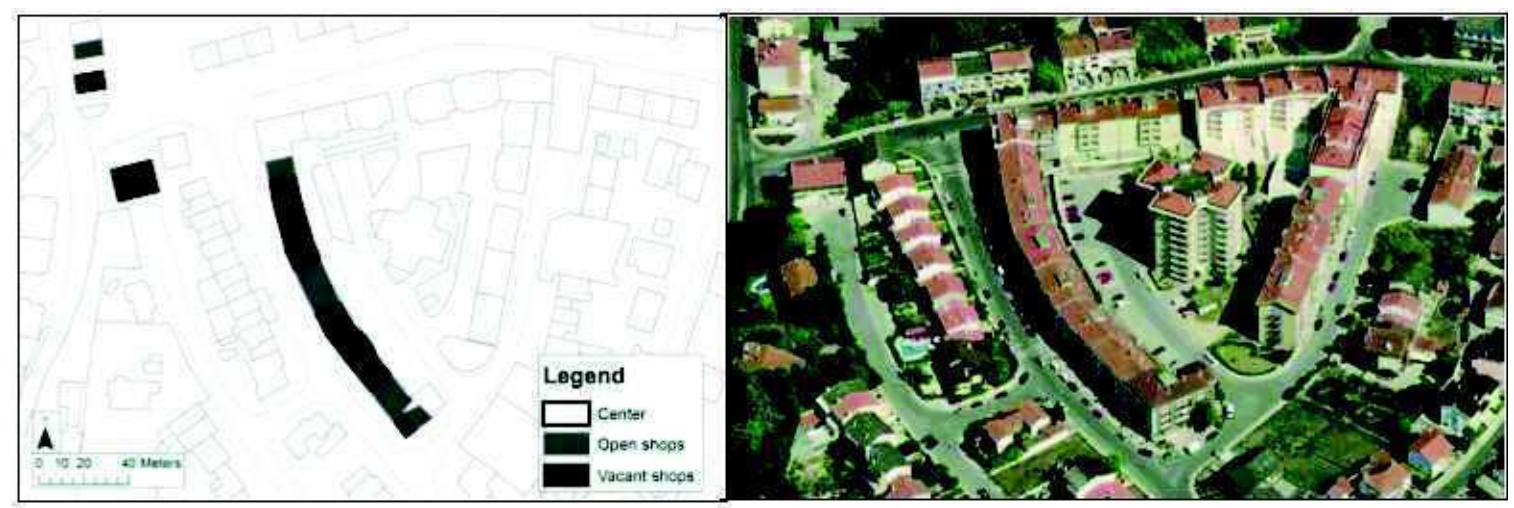

Figure 3.

Model and aerial photograph of the commercial island in Cónego José Pereira Lacerda Street in Marinheiros, Leiria; showing vacant shops (aerial photograph taken from www.bing.com)

inferred that here the increase of commercial offer may have been unjustified, particularly as in many cases bustling commercial arteries are, literally, around the corner. This may also well explain why Évora's city centre has the smallest percentage of vacant shops (40\%): as it is a world heritage site, there is hardly any new construction therein. And it may also explain why Vila Real is the only city with more closed than empty shops. Its traditional historical centre is still the most important commercial hub within the city, and the newer area North of the centre (where most empty shops are located) has not presented and excessive, or excessively competitive, offer.

Most stores which were catalogued as closed (previous occupation was established) are related to first necessity products such as restaurants, cafés and supermarkets; to products for the home, and to Services, either commercial or cultural-related (Table 1). Almost 1 in every 10 'Restaurants \& Cafés' and 'Food \& Beverage' shops in all four city centers was catalogued as closed, as were home-related shops in the centers of Leiria and Évora (9\% and 13\%) and 'Leisure and culture' shops in the center of Vila Real (13\%).

The peripheries contain little less than half of the vacant stores in all cities but Vila Real $(19 \%)$, whose peripheral contains several semi-rural areas, hence little new construction and few shops. Not considering this outlier, a remarkable correlation was found between vacant shops and post 1975 buildings; $77 \%$ in Aveiro, $79 \%$ in Leira and $85 \%$ in Évora. Most are located in what Saraiva and
Pinho (2017) called 'commercial islands'; concentrations of shops on the ground floors of recently constructed multi-family buildings in otherwise entirely residential neighborhoods. Although these 'islands' have tried to respond to the shortage of commercial establishments in these areas (formerly served by few traditional small-scale shops), hardly any is with full commercial occupancy, even those in large residential concentrations. In fact, some display indisputable signs of dereliction. For example, in the Marinheiros' district in Leiria (Figure 3), 9 out of the 15 shops available are vacant, despite the fact that this is one of the most densely populated residential neighborhoods just North of the city center. In Évora, where the periphery has evolved precisely as a series of pockets of residence along expansion axes, the amount of vacant shops in these conditions is the highest.

Consequently being close to market is not necessarily a guarantee of success. In fact, the only store types apparently successful in 'commercial islands' relate mostly to first necessity (newsstands, coffee shops, hairdressers...).

Outside the main residential suburban areas, vacant shops are harder to find, but the total amount of store spaces is also few. Closer to the border of the urban perimeter the smaller and traditional commercial structure (often less than 10 stores) serves a proximity purpose and thus was unaffected by the appearance of new residential neighborhoods and respective 'commercial islands'. Only when these are built too close to the traditional network can 


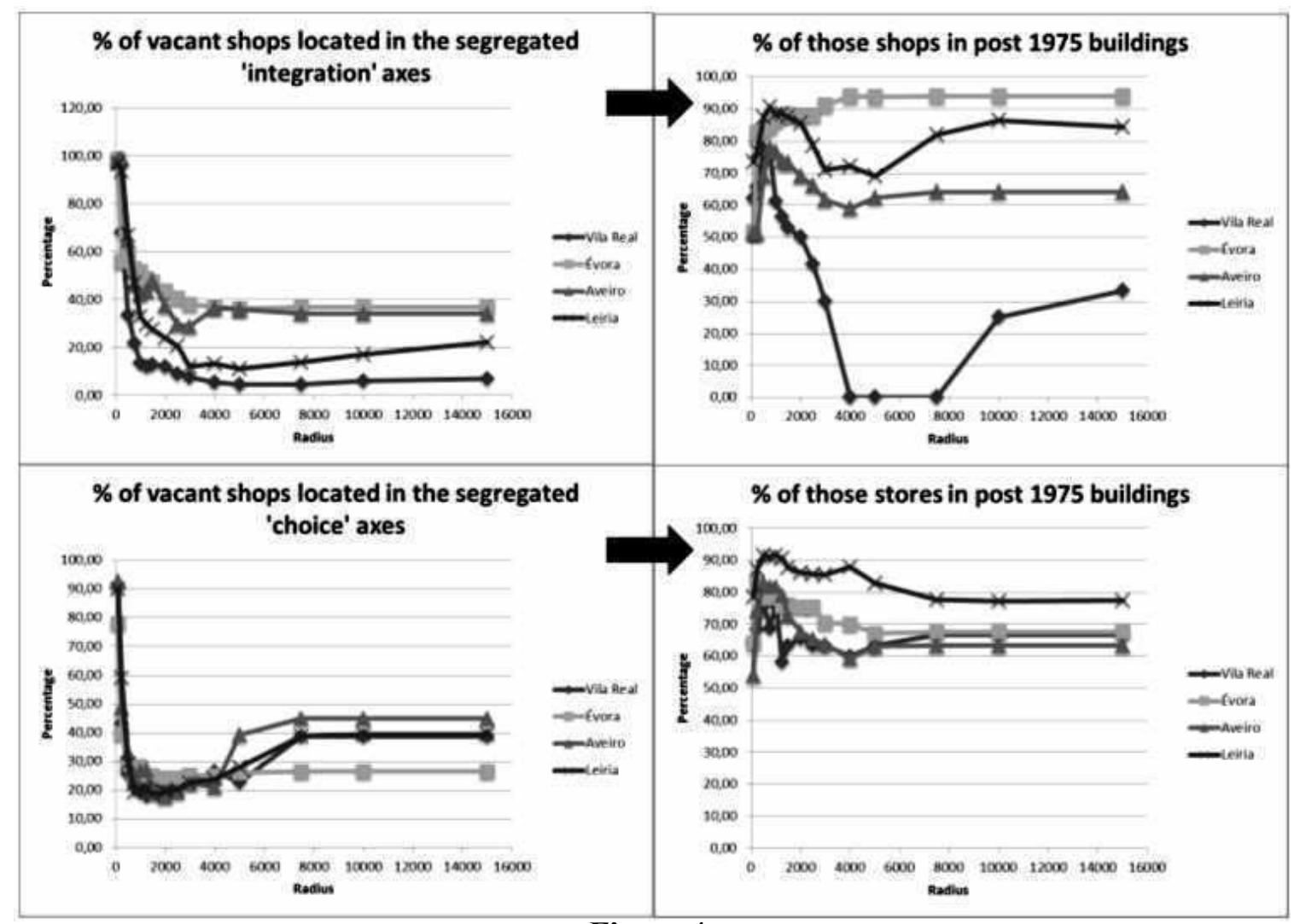

Figure 4.

Percentage of vacant shops located in segregated axes, both for 'choice' and 'integration', and the respective percentage in post 1975 buildings

they become a competitive alternative. In Leiria, 7 out of the 12 shop spaces in a one block radius around the peripheral train station are vacant. But this neighborhood is the area of Leiria with the greatest residential/commercial development in recent years.

Consequently, in peripheries closed stores are mostly associated to restaurants/cafés and the proximity services mainly found in 'commercial islands' (Table 3). Noteworthy is that one fifth of all closed stores in Vila Real's periphery relate to 'Food \& Beverage', denoting the competition of larger supermarkets. 'Leisure and culture' and 'Fashion' establishments also have a tendency to be found closed, both subactivities par excellence of modern multicommercial 'box' formats.

\section{Vacant shops and accessibility}

A Space Syntax segment analysis was performed at various radii. The segments were then divided (using Jenks' 'Natural Breaks') into six quantiles, ranging from the most central (first) to the most segregated (sixth).

Contradicting what has been acknowledged for larger cities, the first noticeable result is that, excluding the local scale (very small radii), less than $40 \%$ of vacant shops are actually located in segregated segments (Figure 4).

The correlation is lowest in Leiria and Vila Real, particularly in terms of 'integration', and in Évora for 'choice'. This can be related to the intrinsic form of these cities. Vila Real and Leiria's peripheries are composed of former satellite villages that slowly become part of the urban perimeter, and thus contain local central streets (natural destinations) where shops are located. On the other hand, Évora has expanded through rays-of-the-sun axes (travel-through thoroughfares) from the city center, and so even commercial 'islands' have much better connection (higher 'choice') than centrality.

Other noticeable result is that with the exception of Vila Real for 'integration' (above mentioned reasons apply), over $60 \%$ of these vacant shops in segregated segments are in post 1975 buildings. 


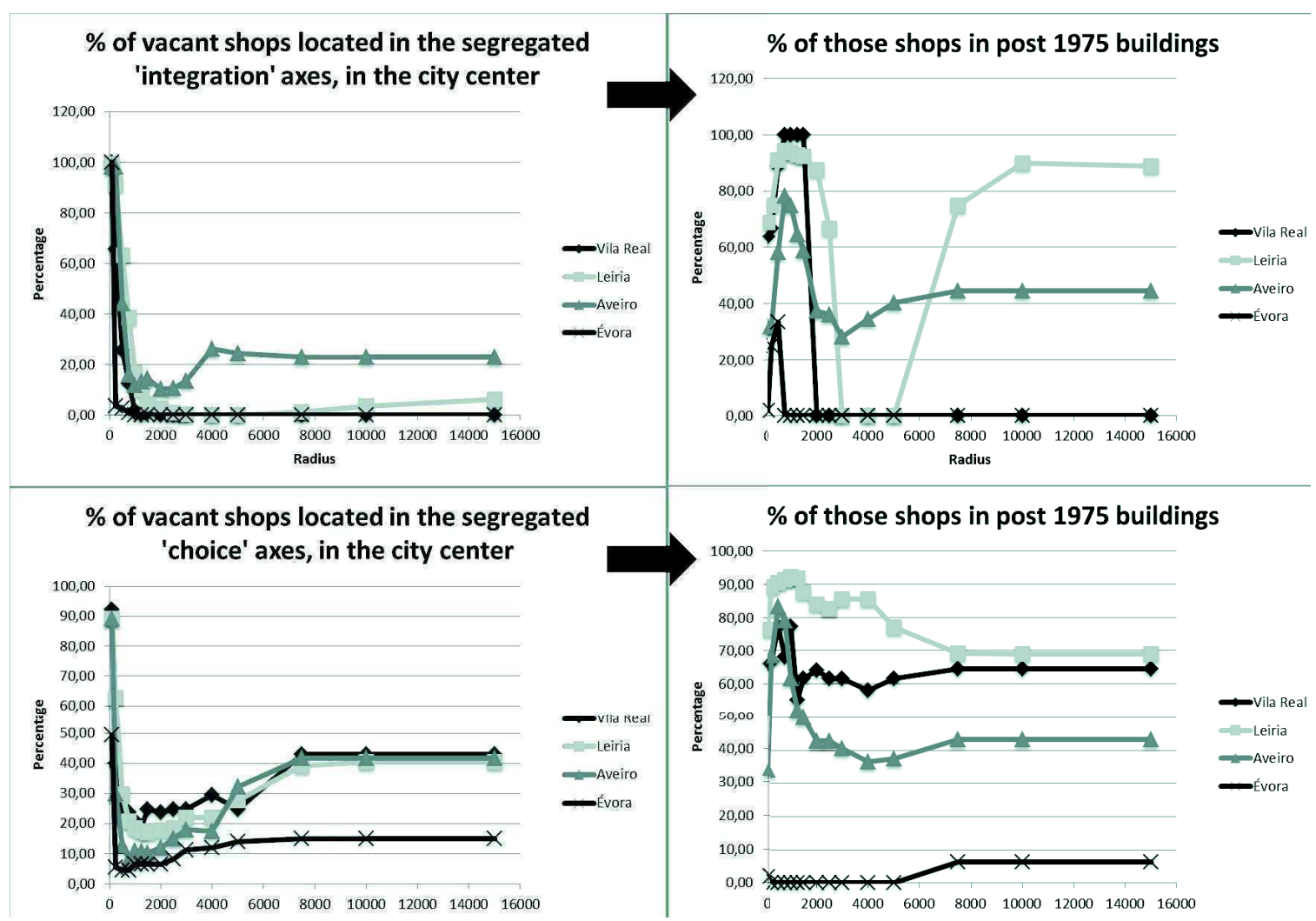

Figure 5.

Percentage of vacant shops, in the centers, that are located in segregated lines, both for 'choice' and 'integration', and the respective percentage in post 1975 buildings

Looking specifically at the city centers (Figure 5) it is confirmed that vacant shops do not have a strong association to segregated segments, with values close to zero after a $1 \mathrm{~km}$ radius except in Aveiro (20\%). This reinforces the notion that these medium-sized city centers are clear overall destinations, even at larger distances, and that shops are mostly located in those centrality axes.

Locally, most vacant shops in segregated segments are in post 1975 buildings. Globally, values drop considerably, particularly in the range between $r=3.000-5.000$ where the potential of centrality of the city centre is maximized (Saraiva, 2013). At higher radii, almost $90 \%$ of Leiria's centre shops in segregated 'integration' segments are in post 1975 buildings, namely newer residential developments at the edge of the centre area. In Aveiro this value is about $40 \%$.

For 'choice' the number of vacant shops in segregated segments is higher, which may corroborate the notion that center shops prefer to be in destinations rather than in distributors. With the exception of Évora's smaller world heritage center, with a retail structured around main axes, the cities display strikingly similar patterns. Locally, $10-20 \%$ of vacant shops are in segregated 'choice' segments, with this number increasing to around $40 \%$ at higher radii. Again, the new residential/service/commercial sites constructed in segregated areas at the edges of the center boundary are the ones which display greater difficulty in finding tenants. Proving this point is the fact that the percentages of these stores in post 1975 buildings is higher (between 70-80\%) precisely in the two centers with more shop spaces in newer buildings: Vila Real's and Leiria's.

In peripheries (Figure 6) and for 'integration', at radii under $\mathrm{r}=2.000$, more than three quarters of vacant shops in Évora and Aveiro, and over half in Leira and Vila Real, are in segregated segments. Furthermore, with the obvious exception of the outlier Vila Real, over $80 \%$ of vacant shops are in buildings constructed after 1975. 'Commercial islands' outside local 


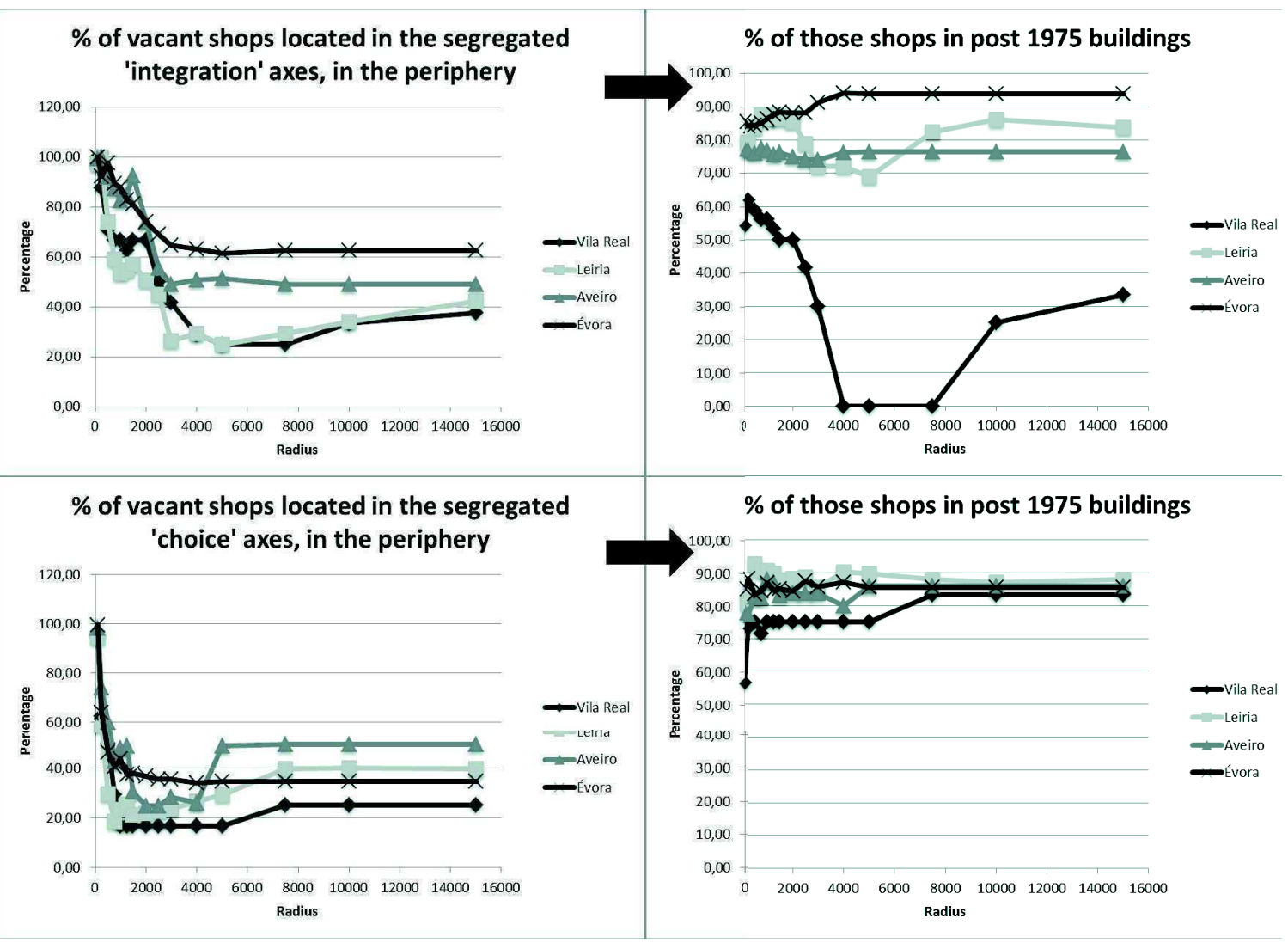

Figure 6.

Percentage of vacant shops, in the peripheries, that are located in segregated lines, both for 'choice' and 'integration', and the respective percentage in post 1975 buildings

centralities thus constitute the hot-spot of vacant shops in the peripheries. Globally, between $40-60 \%$ of vacant shops are in segregated 'integration' segments. The value is greater in Évora, where most commercial islands are within peripheral residential neighborhoods, hence farther from to-movement axes. When a greater portion of the city is more accessible (between $r=3.000$ and $r=7.500$ ) all of Vila Real's periphery vacant shops are in pre-1975 buildings. This is because there are very few new buildings with store spaces in the farthest areas of the urban perimeter.

For 'choice' there are between 20-30\% of vacant shops in segregated segments at a local scale and between $30-50 \%$ at a global scale. The main commercial locations of the suburbs are generally located near throughmovement thoroughfares leading to the city center. Aveiro, with the highest value globally $(50 \%)$ is precisely the city where these connecting axes are fewer. Another evidence is the overwhelming amount of vacant shops in post 1975 buildings in the segregated axes of the suburbia. With the exception of Vila Real for lower radii $(75 \%)$, this number is, for all radii and all peripheries, superior to $85 \%$. Again these seem to relate to commercial islands and other commercial developments which have not complied to what seems to be the periphery's golden rule: shops need to be located close to high 'choice' segments.

\section{Conclusion}

It is generally acknowledged that the reasons for the appearance of vacant shop include the economic crisis, the competition from big 'box' malls and outdated commercial rent laws.

However, there could be other motives. In Portugal, the suburban expansion of the 1990s and municipal policies which stipulated that buildings of a certain size, regardless of 
location, had to contain shop spaces, has led to an excess of offer and consequently to a profuse dispersion of shop spaces (Saraiva and Pinho, 2017). Retailers, unaided by proper commercial planning, opened their shops where they would or could and many commercial locations such as suburban 'commercial islands' or older downtown streets became a derelict scenario of vacant shops.

What this paper has shown is that the importance of the morphological insertion of a shop within a city cannot be neglected. Different shops have different necessities and not all need to be close to market. The way they relate to the building fabric, the network structure and the land-use mix are also important. A high number of shop spaces on a highdensity suburban residential neighbourhood may be excessive, if residents only need first necessity establishments and will perform other types of purchase elsewhere. Vacant shops are intrinsically associated to buildings of relatively recent construction (past 40 years), but also because this construction has led to an exponential increase of commercial area available for rent. It should be questioned whether such area is necessary, taking into account the social and urbanist consequences of vacant shop strips.

The common assumption of Space Syntax literature that stores will underperform in segregated axes may also not be entirely true in suburban areas or smaller-sized cities. A less than expected correlation between segregated segments and vacant shops was found (20$30 \%$ ). This is because most store spaces are in the centres, places where the principal axes of commerce have always a high 'choice' and especially a high 'integration'. Indeed, the case study city centers are clear overall destinations, even at larger distances, and shops need to locate mostly in those centrality axes, highlighting the durability of secular commercial streets. But in peripheries, the correlation is much more perceptible, namely for 'integration'. Open shops are found much more on local than on global centralities, but primarily they are attracted to the distributing travel-through axes.

As Katyoka and Wyatt (2008) state, vacancy may seem a relatively simple concept/problem, but it actually takes on a complexity that needs to be unravelled before drafting and implementing national and local policies and development strategies. Decisionmakers should be concerned with the undesired spatial and socio-economic consequences of commercial transitions. But as Teller (2008) points out, it is much easier to control commercial mix within a private space than in the street. However, mechanisms should be devised to understand for each specific store type not just the economic and geographical, but the urban and hierarchical retail conditions that may guarantee its success. With this goal in mind, the permissiveness of construction in general and of licensing commercial establishments in particular could be substituted by a more comprehensive and demanding vision of how commerce behaves in cities that would ultimately be much more beneficial to urban spaces.

\section{Acknowledgements}

This work was supported by the Portuguese Foundation for Science and Technology under Grant SFRH / BD / 45205 /2008.

\section{References}

Baker, R. G. V. (2002). "The impact of the deregulation of retail hours on shopping trip patterns in a mall hierarchy: an application of the RASTT model to the Sydney Project (1980-1998) and the global vacant shop problem". Journal of Retailing and Consumer Services, 9, 3, 155-171.

Baker, R. G. V. and Wood, S. (2010). "Towards robust development of retail planning policy: Maintaining the viability and vitality of main street shopping precincts". Geographical Research, 48, 1, 65-74.

Balsas, C. J. L. (2014). "Downtown resilience: A review of recent (re)developments in Tempe, Arizona". Cities, 36, 158-169.

Barata-Salgueiro, T. and Erkip, F. (2014). "Retail planning and urban resilience - An introduction to the special issue". Cities, 36 , $0,107-111$. 
Brázio, A. (2013). Vende-se, GHOST Editions Lisboa.

Burns, E. and Willis, E. (2011). "Empty shops in Australian regional towns as an index of rural wellbeing". Rural Society, 21, 1, 2131.

Cachinho, H. (2014). "Consumerscapes and the resilience assessment of urban retail systems". Cities, 36, 0, 131-144.

Colin, J. (2010). "The rise and fall of the high street shop as an investment class". Journal of Property Investment \& Finance, 28, 4, 275-284.

Ferreri, M. (2015). "The seductions of temporary urbanism". ephemera, 15, 1, 181.

Findlay, A. and Sparks, L. (2009). Literature review: policies adopted to support a healthy retail sector and retail led regeneration and the impact of retail on the regeneration of town centres and local high streets. The Scottish Government, Edinburgh.

Gospodini, A. (2012). "Economic Crisis and the Shrinking Greek Cities". 1st International Conference on Architecture \& Urban Design, 2012 EPOKA University, Tirana, Albania.

Hart, P. M. and Dale, R. (2014). "With or without you: The positive and negative influence of retail companions". Journal of Retailing and Consumer Services, 21, 5, 780-787.

Hickman, P. (2013). ““"Third places” and social interaction in deprived neighbourhoods in Great Britain". Journal of Housing and the Built Environment, 28, 2, 221-236.

Hillier, B. and Iida, S. (2005). "Network and Psychological Effects in Urban Movement". In: Cohn, A. \& Mark, D. (eds.) Spatial Information Theory. Springer Berlin Heidelberg, 475-490.

Jingnan, Z. (2009). Study on the Spatial Structure of Large Scale Retail Stores Based on Space Syntax: Case Study in Wuham. Master of Science in Geo-information Science and Earth Observation.

Joosten, V. and Van Nes, A. (2005). "How block typology influences the natural movement economic process - Micro spatial conditions on the dispersal of shops and cafés in Berlin". Delft University of Technology (MSc \& paper).
Katyoka, M. and Wyatt, P. (2008). "An investigation of the nature of vacant commercial and industrial property". Planning, Practice \& Research, 23, 1, 125145.

Michou, M. (2013). "Athens streetside arcades: silent gestures of minor occupation". Urbanistica, 1, 3, 29-36.

Pecoraro, M. and Uusitalo, O. (2014). "Exploring the everyday retail experience: The discourses of style and design". Journal of Consumer Behaviour, 13, 6, 429-441.

Porta, S., Strano, E., Iacoviello, V., Messora, R., Latora, V., Cardillo, A., Wang, F. H. and Scellato, S. (2009). "Street centrality and densities of retail and services in Bologna, Italy". Environment and Planning B-Planning \& Design, 36, 3, 450-465.

Reimers, V. and Clulow, V. (2004). "Retail concentration: a comparison of spatial convenience in shopping strips and shopping centres". Journal of Retailing and Consumer Services, 11, 4, 207-221.

Saraiva, M. (2013). The morphological sense of commerce: Symbioses between commercial activity and the form and structure of Portuguese medium-sized cities. $\mathrm{PhD}$ in Civil Engineering - Planning of Environment and Territory, Faculty of Engineering of the University of Porto.

Saraiva, M. and Pinho, P. (2017). "Spatial modelling of commercial spaces in mediumsized cities". GeoJournal, 82, 3, 433-454.

Sarma, A. (2006). The social logic of shopping - A syntactic approach to the analysis of spatial and positional trends of community centre markets in New Delhi. MSc Built Environment: Advanced Architectural Studies, University College London, Bartlett School of Graduate Studies.

Teller, C. (2008). "Shopping streets versus shopping malls - determinants of agglomeration format attractiveness from the consumers' point of view". The International Review of Retail, Distribution and Consumer Research, 18, 4, 381-403.

Van Nes, A. (2005). "Typology of shopping areas in Amsterdam". In: Nes, E. A. v., ed. Proceedings Space Syntax. 5th International Symposium, 2005 TU Delft, Amsterdam. Techne Press. 
Villain, J. (2011). The impact of urban form on the spatial distribution of commercial activities in Montréal. M.SC thesis.

Whysall, P. (2011). "Managing decline in inner city retail centres: From case study to conceptualization". Local Economy, 26, 1, 3-17.

Wrigley, N. and Dolega, L. (2011). "Resilience, fragility, and adaptation: new evidence on the performance of UK high streets during global economic crisis and its policy implications". Environment and Planning A, 43, 10, 2337-2363.

Yoshida, H. and Omae, M. (2005). "An approach for analysis of urban morphology: methods to derive morphological properties of city blocks by using an urban landscape model and their interpretations". Computers, Environment and Urban Systems, 29, 2, 223-247.

Ziehl, M. and Oßwald, S. (2015). "Practices in second hand spaces: Producing value from vacancy". ephemera, 15, 1, 263-277. 